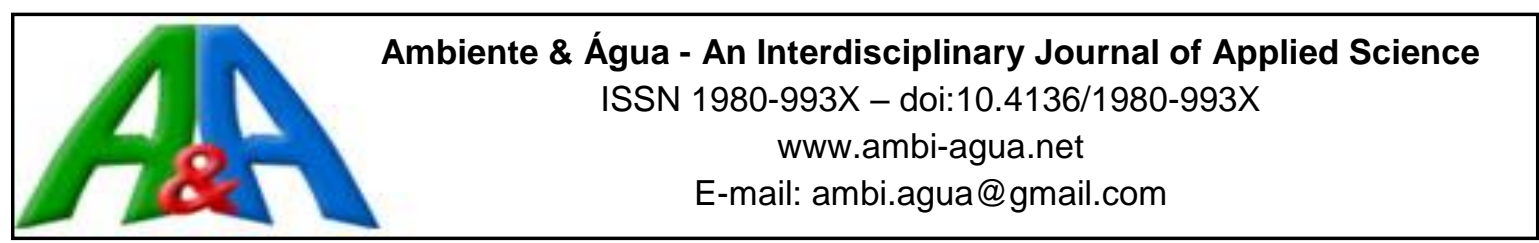

\title{
Sensitivity of hydrological connectivity in a semiarid basin with a high- density reservoir network
}

\author{
ARTICLES doi:10.4136/ambi-agua.2367
}

Received: 27 Nov. 2018; Accepted: 29 Apr. 2019

\author{
Cristian Epifanio Toledo $^{1 *(D)}$; Nayra Rodrigues Alcantara ${ }^{2}$ (D) \\ ${ }^{1}$ Universidade Estadual de Goiás (UEG), Palmeiras de Goiás, GO, Brasil \\ Departamento de Agronomia. E-mail: cristian.toledo@ueg.br \\ ${ }^{2}$ Universidade Federal de Goiás (UFG), Goiânia, GO, Brasil \\ Instituto de Patologia Tropical e Saúde Pública (IPTSP). \\ E-mail: bionaybio@gmail.com \\ *Corresponding author
}

\begin{abstract}
Water reservoirs, in general, have been considered to be the major cause of reduction of downstream hydrological connectivity in channels. Therefore, this study analyzed the sensitivity of hydrological connectivity in the Orós Reservoir hydrographic basin by using the ResNet model, designed to simulate the processes involved in fluvial hydrological connectivity in environments with a high density of reservoirs. The analysis of hydrological connectivity was performed with the model ResNetM, which simulated hydrological processes and considered hydrological connectivity between the reservoirs, according to the criteria established in this research. To identify the main elements that affect hydrological connectivity, sensitivity analysis (SI) was performed of some input parameters of the model. The sensitivity analysis indicated that the modification of the topology of the reservoir network was the variable that presented the highest sensitivity to hydrological connectivity, with a sensitivity value of 1.07 , followed by the runoff coefficient, which obtained a sensitivity of 0.8 . The modification of the rainfall and of the reservoir storage capacity, showed an intermediate sensitivity, with values of 0.46 and 0.45 , respectively. On the other hand, the parameters of potential evaporation and transmission loss showed the lowest sensitivity, obtaining values of 0.19 and 0.01 , respectively. In conclusion, the runoff coefficient and the reservoir network (change in the reservoir number of the network) were the parameters evaluated with the highest sensitivity of hydrological connectivity. Thus, the alteration of the landscape by man provides significant changes in river navigation between the reservoirs in the basin.
\end{abstract}

Keywords: climate changes, hydrological modeling, sensitivity analysis.

\section{Sensibilidade da conectividade hidrológica em uma bacia semiárida com uma rede de alta densidade de reservatórios}

\section{RESUMO}

Os reservatórios de água, em geral, têm sido considerados a principal causa de redução da conectividade hidrológica a jusante nos canais. Portanto, este estudo tem como objetivo analisar a sensibilidade da conectividade hidrológica na bacia hidrográfica do reservatório de Orós, utilizando o modelo ResNet, desenvolvido para simular os processos envolvidos na 
conectividade hidrológica fluvial em ambientes com alta densidade de reservatórios. A análise da conectividade hidrológica foi realizada com o modelo ResNetM, que simulou processos hidrológicos e considerou a conectividade hidrológica entre os reservatórios, de acordo com os critérios estabelecidos nesta pesquisa. Para identificar os principais elementos que afetam a conectividade hidrológica, foi realizada a análise de sensibilidade (SI) de alguns parâmetros de entrada do modelo. A análise de sensibilidade indicou que a modificação da topologia da rede de reservatórios foi a variável que apresentou maior sensibilidade à conectividade hidrológica, com um valor de sensibilidade de 1,07, seguido do coeficiente de escoamento, que obteve uma sensibilidade de 0,8. A modificação da precipitação pluviométrica e da capacidade de armazenamento do reservatório mostrou uma sensibilidade intermediária, com valores de 0,46 e 0,45 , respectivamente. Por outro lado, os parâmetros de potencial evaporação e perda de transmissão, apresentaram a menor sensibilidade, obtendo valores de 0,19 e 0,01, respectivamente. Conclui-se que o coeficiente de escoamento e a rede de reservatórios (mudança no número do reservatório da rede) foram os parâmetros avaliados com a maior sensibilidade de conectividade hidrológica. Assim, a alteração da paisagem pelo homem, proporciona mudanças significativas na navegação fluvial entre os reservatórios da bacia.

Palavras-chave: análise de sensibilidade, modelagem hidrológica, mudanças climáticas.

\section{INTRODUCTION}

In the northeast region of Brazil, classified as a semi-arid region, the construction of reservoirs has been the main decision adopted by water resource managers and by the civil population in order to try to solve the problem of water scarcity in the region over time (Malveira et al., 2012; Toledo et al., 2014). On average, there is one severe drought every decade, which sometimes lasts for many years (Araújo and Bronstert, 2015) - for example, from 2012 to 2015 (Marengo et al., 2017). This reservoir construction policy often occurs without any control or use of technical-scientific knowledge. As a result, a "high-density reservoir network" is produced, with predominantly small- and medium-sized reservoirs, which turns out to be a complex system to manage (Araújo and Piedra, 2009).

Reservoirs have been considered to be the major cause of changes to water flow dynamics in water bodies, thus provoking disruption of hydrological connectivity. Hydrological connectivity in channels or rivers has been evaluated by analysis of water flow continuity in their riverbeds. For this purpose, a minimum flow rate index is used to characterize such hydrological connectivity (Brozovic et al., 2011; Fryirs, 2012; López-Vicente et al., 2013; Garbin et al., 2019). This flow can be measured by fluviometric methods, by injection dilution gauging (Burke, 2009) and also by simulations in hydrological models (Döll et al., 2003; Hanasaki et al., 2010; Malveira et al., 2012; Sun et al., 2015). Lane et al. (2009) highlight that hydrological models have a very important role in hydrological connectivity, as they enable temporal variation and structural connectivity to be checked.

A hydrological model can be defined as a tool of mathematical representation of water flow rate and its interactions with the atmosphere and the terrestrial surface; in other words, representation of hydrological processes that occur in a water basin. This mathematical representation uses a series of parameters, which simulate the characteristics of the environment and modeled physical processes; often, it requires previous calibration and/or sensitivity analysis of these parameters. (Yang et al., 2015; Silva et al., 2015).

Sensitivity analysis enables the identification and definition of the input elements of a model that cause the greatest disturbance in the performance of the output results, that is, how much the output values are affected by changes in input values (Loucks and Van Beek, 2005). Sensitivity analysis helps users to define which elements should be estimated with more 
precision or accuracy, because these are of great relevance for the processes being evaluated. Kruk et al. (2009) noted that knowledge of the sensitivity of the elements of a hydrological model is extremely important to direct field research and to select parameters for future research.

In this context, the general objective of the present study was to perform sensitivity analysis of hydrological connectivity in the water basin of Orós Reservoir by using the ResNet model, designed to simulate the processes involved in fluvial hydrological connectivity in environments with a high density of reservoirs.

\section{MATERIALS AND METHODS}

The study area is the Orós Reservoir Basin, which is nestled at the Alto Jaguaribe Basin (BAJ). The basin is located in the southeast portion of the State of Ceará, in 24 South zone, between the 292000 and $508300 \mathrm{~m}$ abscissas, and the 9180000 and $9409000 \mathrm{~m}$ ordinates, of the rectangular plane UTM for datum WGS - 1984. It has a drainage area of $24211 \mathrm{~km}^{2}$, which corresponds to $97 \%$ of BAJ and $16 \%$ of the State of Ceará, approximately. The climate of the basin, according to Köppen classification, is Bsh, characterized as a steppe's climate, with an average annual temperature of $28^{\circ} \mathrm{C}$. Annual precipitation ranges between 500 and $1000 \mathrm{~mm}$, with an average of $751 \mathrm{~mm}$. It occurs mostly from January to May, with marked irregularity in time and space. Annual potential evaporation in the study area is in the order of $2200 \mathrm{~mm}$. Geologically, it is formed mainly by Precambrian crystalline basement rocks $(81 \%$ of its territory) and, on a smaller scale, by sedimentary deposits (19\%).

The dominant superficial runoff is Hortonian, which generates from 10 to $70 \mathrm{~mm}$ annually. The typical superficial runoff coefficient ranges from 5 to $12 \%$. The main water source of Orós Reservoir Basin is based on the reservoirs spread out in the basin. Toledo et al. (2014), based on satellite images, identified 4717 public and private reservoirs in the basin in 2011 (Figure 1), with a total water storage capacity of $3646 \mathrm{hm}^{3}$. Eighteen reservoirs of this High-density Reservoir Networks (HdRN) are considered to be strategic for water resource management of the basin; they are monitored by the Companhia de Gestão dos Recursos Hídricos do Estado do Ceará (COGERH) (Water Resources Management Company of the State of Ceará).

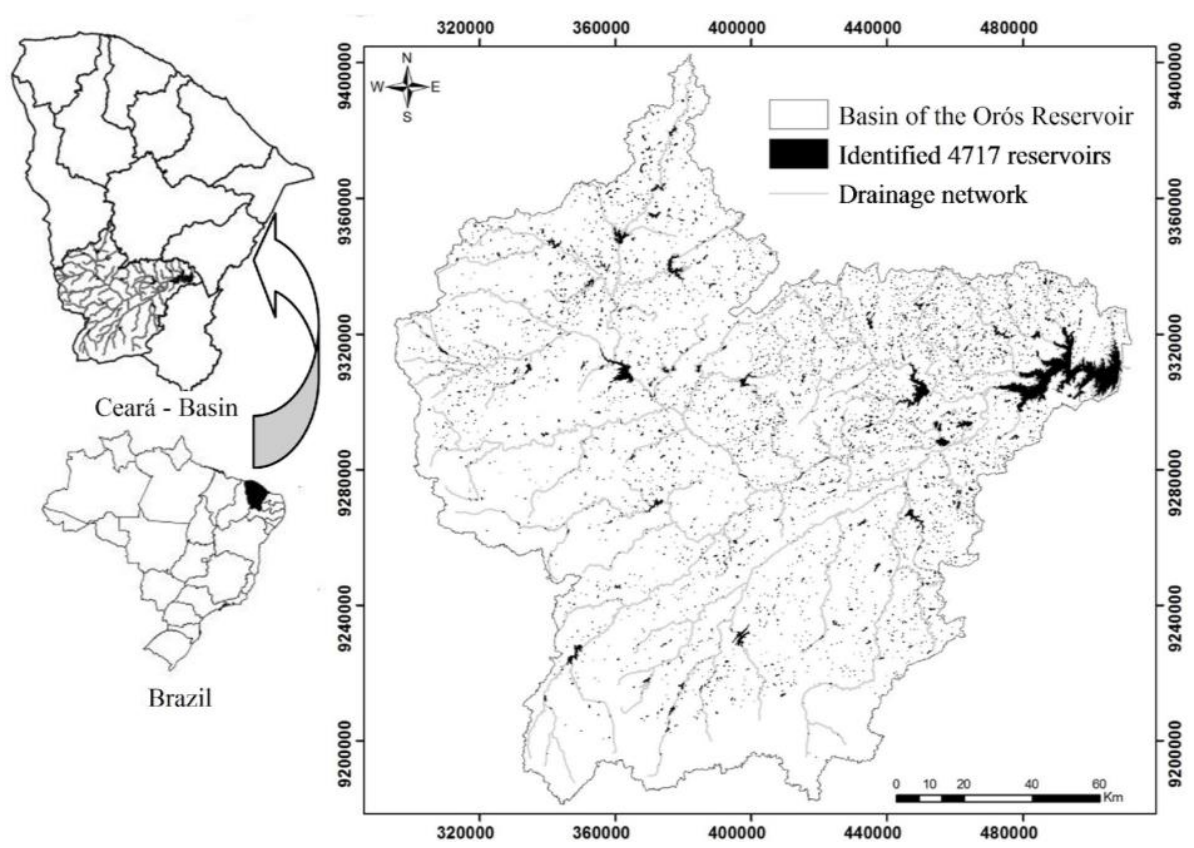

Figure 1. Localization and spatial distribution of the 4717 identified reservoirs, in 2011, in the hydrographic basin of Orós dam (BHAO). 
The hydrological model chosen for the present study was the Reservoir Network Model ResNetM, designed by the study group Grupo de Estudos Hidrosedimentológico do Semiárido - Hidrosed, to simulate the hydrological processes and enable the study of hydrological connectivity in the semiarid environment, while approaching a simplified water balance for each reservoir. The model has the advantage of requiring few input data and low processing time, even when considering the thousands of reservoirs in the basin. This enables intensive studies of its parameters, e.g., sensitivity analysis (Peter et al., 2014).

In the ResNetM model, the dense reservoir network is simulated as a tree, while respecting the location of each reservoir. In this tree, the reservoirs are the vertices or nodes and the connections between them are the branches, with a focus on complex network theory. The reservoirs located at the extremity show only one downstream reservoir and the other "intermediary" reservoirs are spread in the basin; there may be many upstream reservoirs, but only one downstream reservoir. The branches correspond to the draining networks of the basin, which connect the reservoirs. Their direction is determined according to the topography of the terrain, and for this reason, it does not enable the formation of cycles between vertices or reservoirs.

The model begins the interaction between the reservoirs by computing the superficial runoff generated in the sub-basin of each reservoir. Then, the resulting runoff is transferred to the reservoir, where water balance is performed. The flow generation and water balance system begins by the most upstream reservoirs of the network; the flow is transferred in the form of cascades between the sub-basins to the most-downstream reservoir, namely, the Orós Reservoir, considered to be the output vertex of the system, when there is no other downstream reservoir.

The hydrological connectivity of the reservoirs is characterized by the presence of a fluvial flow throughout the whole path of the river between the reservoir and the downstream mouth, whether it is a mouth, a river (affluence), or a new reservoir. In order to possibly acknowledge that the reach was connected, the flow rate could not be lower than a minimum reference flow rate (Speir et al., 2016). A minimum reference flow rate of $1.0 \mathrm{~L} \mathrm{~s}^{-1}$ is adopted, according to Art. 6-o, subsection III, of Resolution 707/2004 from National Water Agency - ANA. Therefore, whenever the flow rate in the upstream reservoir and in the mouth of the reach exceeded $1 \mathrm{~L} \mathrm{~s}^{-1}$, hydrological connectivity of the reach was acknowledged.

Once the hydrological connectivity criteria have been established, the ResNet model can check the Hydrological Connectivity Indicator (HCI) which occurred in the basin. The HCI is estimated by the ratio between the quantity of connected reservoirs (number of hydrologically connected reaches - NHCR) and the product of the total number of reaches in the basin and the number of days of the simulation (Equation 1).

$$
H C I=\frac{N H C R}{T N \times N D}
$$

Where:

NHCR is the total number of hydrologically connected reaches (-); TN is the total number of reaches in the basin (-) and ND is the number of simulated days (days).

The input parameters considered in the sensitivity analysis of the ResNetM model were rainfall $(\mathrm{P})$, potential evaporation $(\mathrm{Ep})$, superficial runoff coefficient $(\mathrm{CR})$, transmission loss coefficient $(\mathrm{K})$, storage capacity of the reservoirs (CA) and reservoir network (Rn). The evaluated output variable was the Hydrological Connectivity Indicator (HCI).

The sensitivity of each parameter was estimated by the Sensitivity Index of Nearing et al. (1990) (Equation 2), which represents the normalized change generated in the output to a

Rev. Ambient. Água vol. 14 n. 4, e2367 - Taubaté 2019 
normalized change in data input. In this way, the furthest from zero IS is, the more sensitive the model is for the input parameter, regardless of whether this value is positive or negative.

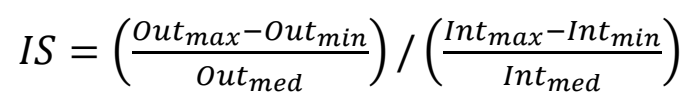

Where:

IS is the sensitivity index of the input parameters; $\mathrm{Int}_{\max }$ and $\mathrm{Int}_{\min }$ are the maximum and minimum values used in the variation of the input parameter; Out ${ }_{\max }$ and $\mathrm{Out}_{\min }$ are the output values for $\mathrm{Int}_{\max }$ and $\mathrm{Int}_{\min }$, respectively; $\mathrm{Int}_{\mathrm{med}}$ and Out $\mathrm{t}_{\mathrm{med}}$ are the averages of input and output values, respectively.

In order to make changes to the values of input parameters, scenarios were created to describe possible alterations that can occur at a particular time in the system. Therefore, each alteration in the input parameter values of the model gave rise to a scenario (Ceteris Paribus principle), which was simulated with the same time period of the current system of the basin (1991 to 2011). These alterations have the following characteristics, the reference rainfall height was reduced by $5,10,15,20,25,30,35,40,45$ and $50 \%$, and also increased by 5, 10, 15 and $20 \%$. These values were based on studies which evaluated the effects of climate change in rainfall until 2100 in Brazilian Semiarid (Krol et al., 2011). The potential evaporation of the scenarios were set up to increase the Ep reference value by 1, 5, 7, 10 and 15\%; these values were based on Krol et al. (2011). Although there was a lack of scientific evidence for a possible decrease of Ep in the region, a reduction in Ep values was simulated in the same proportions of the increase $(-1,-5,-7,-10$ and $-15 \%)$, thus generating another 10 scenarios.

- Runoff Coefficient (RC): in the variation of $\mathrm{RC}$, the scenarios were arranged by multiplying the specific $\mathrm{RC}$ reference values from the 18 sub-basins of the strategic reservoirs by the factors of $0.10 ; 0.25 ; 0.50 ; 0.75 ; 1.25 ; 1.50 ; 1.75$ and 2.00 , which represent the possible changes in the landscape from soil use and occupation.

- Transmission Loss Coefficient $(\mathrm{k})$ : changes in the reference value of transmission loss were made multiplying the $\mathrm{K}$ reference value by the factors of $0.10,0.25,0.50,0.75,1.25$, $1.50,1.75$ and 2.00 , in order to simulate a possible variation in water abstraction from rivers, as a result of anthropic factors and/or predicted climate changes for the region in this millennium (Krol et al., 2011);

- Reservoir storage capacity (Ca): simulated by varying $+5,+25,+50,+75,+100,-5,-25$, -50 and $-70 \%$. As a result, the strategic reservoirs did not suffer variations in their storage capacity;

- Reservoir Network (Rn): sensitivity of hydrological connectivity to the presence of thousands of reservoirs was calculated by modifying the reservoir network topology. The reservoirs from Class $1\left(<0.1 \mathrm{hm}^{3}\right)$, Class $2\left(0.1-1 \mathrm{hm}^{3}\right)$ and Class $3\left(1-3 \mathrm{hm}^{3}\right)$ were gradually excluded from the network, and three "artificial" networks were generated, namely, Rn1, Rn12 and Rn123, respectively.

To evaluate the behavior of the scenarios and determine the effect of the dense reservoir network on hydrological connectivity, investigations were made regarding the ratio between the HCI of the scenarios and the total volume stored in the basin, as well as the volume stored in the Orós Reservoir.

\section{RESULTS AND DISCUSSION}

Sensitivity analysis (Sensitivity Index - SI, Table 1) of the hydrological connectivity demonstrated high sensitivity $(\mathrm{SI}>0.80)$ to variation in the reservoir network $(\mathrm{SI}=1.07)$ and 
to runoff coefficient $(\mathrm{SI}=0.84$ ) and moderate sensitivity ( $\mathrm{SI}=0.40$ to 0.80 ) to variation in storage capacity of non-strategic reservoirs $(\mathrm{SI}=0.45)$ and rainfall alteration $(\mathrm{SI}=0.46)$. However, hydrological connectivity in Orós Reservoir Basin has low sensitivity to potential evaporation $(\mathrm{SI}=0.19)$ in the reservoirs and even lower to transmission loss in rivers and streams $(\mathrm{SI}=0.003)$.

Table 1. Sensitivity Index (SI) of hydrological connectivity for the main input parameters of ResNetM model.

\begin{tabular}{lcccc}
\hline \multirow{2}{*}{ Input parameter } & \multirow{2}{*}{ Reference input value } & \multicolumn{2}{c}{ Interval of values } & \\
\cline { 3 - 4 } & & Input & ICH $(\%)$ & \\
\hline Rainfall $(\mathrm{mm})$ & 1.88 & $0.94-1.97$ & $4.94-7.25$ & 0.46 \\
Potential evaporation $\left(\mathrm{mm}\right.$ month $\left.^{-1}\right)$ & 207.8 & $176.6-209.9$ & $7.03-6.57$ & 0.19 \\
Runoff coefficient $(-)$ & 0.03 & $0.003-0.06$ & $2.17-8.20$ & 0.84 \\
Transmission loss $\left(\mathrm{km}^{-1}\right)$ & 0.027 & $0-0.054$ & $6.79-6.76$ & 0.01 \\
Reservoir storage capacity $\left(\mathrm{hm}^{3}\right)$ & 0.73 & $0.18-1.46$ & $8.69-5.48$ & 0.45 \\
Reservoir network $(-)$ & 4717 & $53-650$ & $4.00-5.84$ & 1.07 \\
\hline
\end{tabular}

The variations of parameters $\mathrm{k}$ and $\mathrm{P}$ resulted in alteration of HCI in a "stable" rhythm, resulting in a linear tendency (Figure 2), in which a low slope refers to the axis of abscissas. The low sensitivity of hydrological connectivity to evaporation (Ep) can be explained by the period in which the highest HCI values occurred, in the rainy season of the basin. Consequently, in the rainy season, the atmospheric abstractions decrease and thereby volumetric losses in the reservoirs are small, hence not enough to significantly affect the HCI of the basin. In the case of transmission loss (k), the low sensitivity of hydrological connectivity is due to the short extension of the reaches. The thousands of reservoirs present in the basin break the draining network in short reaches (average size of $1.89 \mathrm{~km}$ ), and consequently, water losses in these reaches become small: on average $5.1 \%$ of fluvial flow rate.

Initially, it was thought that amongst the "natural" elements, rainfall would promote the largest variations in the HCI of Orós Reservoir Basin. However, this moderate influence of rainfall over hydrological connectivity can be explained by the type of modification performed in rainfall. Rainfall variations altered the height captured directly by the reservoirs and the runoff volume in sub-basins, yet it did not influence the number of days with rainfall, and it modified the runoff coefficient to an even lesser degree. This coefficient varies according to the presence of previous rainfall, regardless of height.

It is believed that high sensitivity of hydrological connectivity to variation in runoff coefficient (CR) is linked to the process of (Hortonian) runoff generation in the region. In the process of Hortonian runoff, rainfall intensity must surpass infiltration capacity for runoff to occur. In long hillslopes, the runoff generated upstream can re-infiltrate (Medeiros et al., 2010; Safeeq and Fares, 2012). It has already been seen in other studies that the average annual rainfall below the average indicates conditions of low hydrological connectivity when compared to the average and temporarily well distributed rain years (Fryirs, 2012). Since connectivity is understood as the transfer of matter between two distinct topographical points, the identification of the connectivity patterns in a river basin allows the investigation of the cumulative impacts of small reservoirs of water resources (Lopes and Pinheiro, 2015).

In this way, soil infiltration capacity, represented inversely by the runoff coefficient (CR), becomes determinant in the process of superficial runoff re-infiltration, thus influencing directly the flow that reaches the draining network and, consequently, the hydrological connectivity of the basin. For example, when the CR parameter was increased by $50 \%$, the possibility of superficial runoff re-infiltration decreases. The repercussions of such lower re-

Rev. Ambient. Água vol. 14 n. 4, e2367 - Taubaté 2019 
infiltration was that the runoff volume which reached the draining network increased and, consequently, the HCI value was $13 \%$ higher than the reference HCI. When the CR was reduced in the same magnitude $(-50 \%)$, the probability for the superficial runoff to re-infiltrate increased, thus reducing the runoff volume, and the HCI decreased by $29 \%$, when compared with the reference value. That can be influenced by several factors; a study conducted by Rodrigues et al. (2013), observed changes in surface runoff as a consequence of the partial removal of vegetation by thinning; while in other events the average leaflet depth was higher in the preserved micro basin. Those results revealed that the practice of caatinga thinning presented modifications, presented values of drained slides inferior to those of the preserved micro basin; it was verified, however, that the maximum discharges in the thinned micro basin were superior to those of the preserved basin.
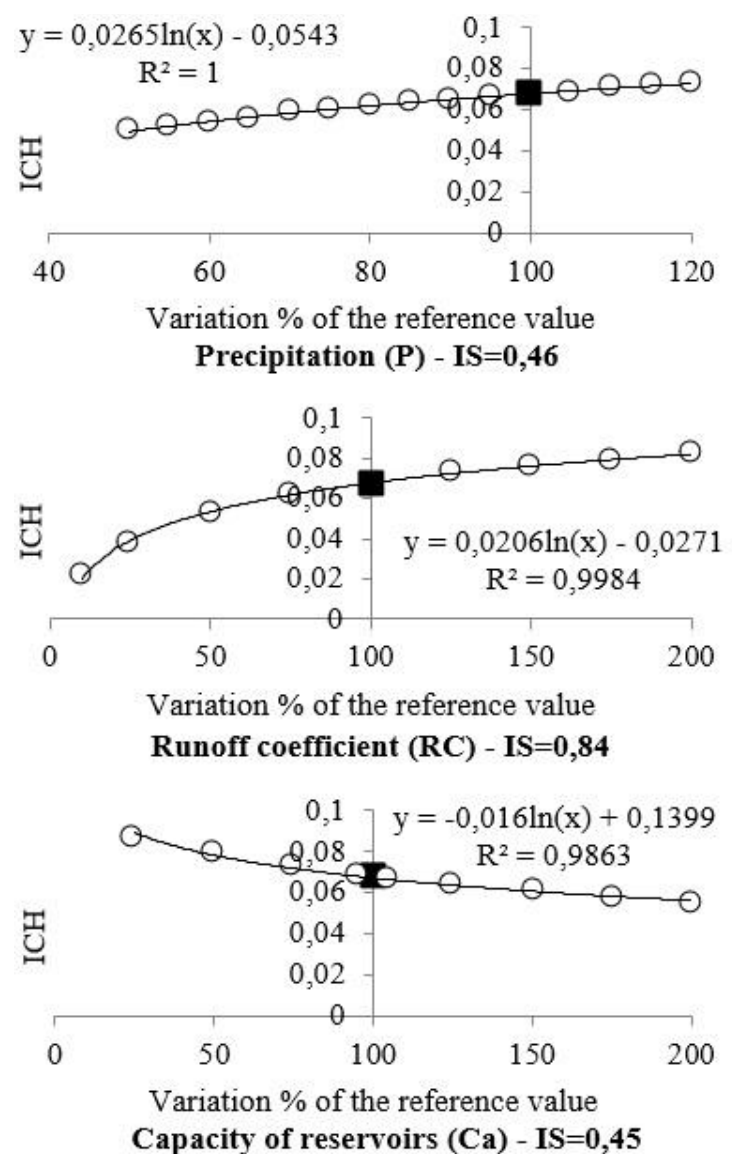
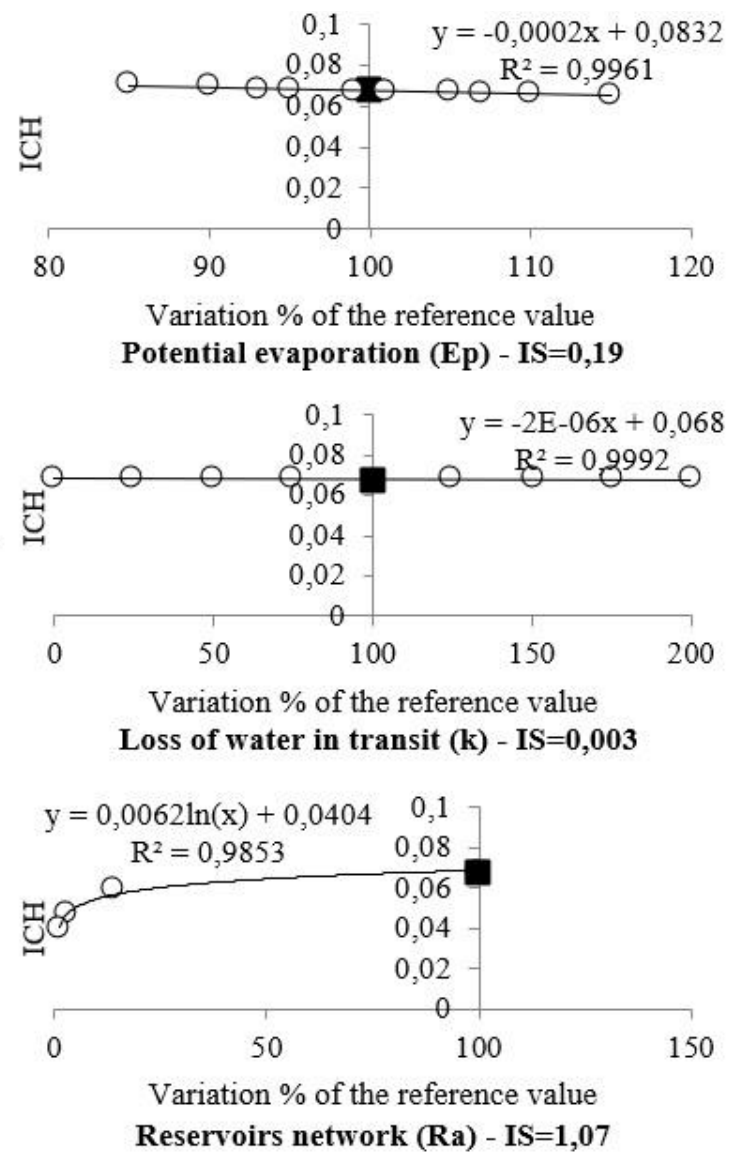

Reservoirs network (Ra) - IS $=1,07$

Figure 2. Values of hydrological connectivity index (ICH) obtained in BHAO, as a function of input parameters variation from ResNetM model for the period of 2001 to 2011.

In the case of variation in the reservoir network topology, the high sensitivity of hydrological connectivity confirms that anthropic intervention in the environment has been significantly interfering in the fluvial flow regime of a basin. As simulated, after removal of thousands of small- and medium-sized reservoirs of the reservoir-dense network of Orós Reservoir Basin, the HCI was significantly reduced (41\% compared with the reference HCI). This indicates that the small- and medium reservoirs, even in the presence of minor fluvial floods, are capable of producing an effluent flow (sangria) enough to overcome the transmission losses (small reaches) and connect with the downstream reservoir. However, without the thousands of reservoirs, the minor floods normally are not capable of generating hydrological connectivity between the reservoirs.

The prominent roles of rainfall, reservoir network topology and superficial runoff properties over hydrological connectivity have been addressed in other hydrological studies as 
well as in ecological ones (Callow and Smettem, 2009; Hall et al., 2012; Long and Pavelsky, 2013). Bracken and Croke (2007) found that, in the scale of a hydrographic basin in semiarid areas, hydrological connectivity usually requires high intensity rainfall uniformly distributed throughout the basin, while slope connectivity can be initiated by short-lasting rainfall, or by less intense events. However, the authors have warned that each hydrographic basin has a spatial base pattern in terms of hydrological connectivity, which depends, primarily, on the runoff generating areas and on the rainfall-runoff relation.

In regard of the influence of the dense-reservoir network topology, Jackson and Pringle (2010) argue that the thousands of small reservoirs alter the hydrological connectivity of terrestrial landscape in innumerable ways. They hold from 81 to $98 \%$ of sediments and nutrients that are affluent to these reservoirs; they block or prevent the longitudinal movements of aquatic organisms; they transform lotic habitats into lentic habitats; and they alter the temporal series of downstream flows.

In regard of superficial runoff, Bracken and Croke (2007) point out that, in semiarid and arid environments, hydrological connectivity occurs differently compared with humid and temperate areas because Hortonian is the most common type of runoff. As a general rule, hydrological connectivity in semiarid and arid environments is harder to achieve and occurs less frequently than in temperate and humid areas. This difference in hydrological connectivity between dry and temperate/humid areas is due to many factors, for example, precedent conditions of soil humidity.

A good correlation $\left(\mathrm{R}^{2}=0.74\right)$ was found after an analysis of the relation between the volume of water stored in the basin and the HCI (Figure 3). One can notice that, when modifying the HCI, the volume stored in the basin follows the same tendency; that is, when the HCI decreased, the volume stored in the basin decreased as well; when the HCI increased, the stored volume increased. However, when the HCI is lower than 5.5\%, the volume stored in the basin reduces more rapidly. This shows that the volume stored in Orós Reservoir Basin is more sensitive ( $\mathrm{SI}=1.83$ ) to a reduction of the reference $\mathrm{HCI}$ than to an increase ( $\mathrm{SI}=0.26)$. The results confirmed that hydrological connectivity can be a good indicator of water availability in semiarid hydrographic basins.

An evaluation of the influence of HCI variation over the behavior of the volume stored in Orós Reservoir, showed that the influence of natural elements is different from the influence of anthropic elements (Figure $3 \mathrm{~A}$ and B). The reduction in HCI caused by one of the natural elements being analyzed - for example, superficial runoff $(\mathrm{CR})$ or rainfall $(\mathrm{P})$ - would cause a significant reduction in the volume stored in Orós reservoir $(\mathrm{SI}=1.45)$. In other words, there would be lower water availability in the reservoir.

The reduction or increase of HCI caused by changes to one of the anthropic elements being analyzed, that is, the increase or reduction in storage capacity of the reservoirs or alteration in the reservoir network topology, did not entail expressive changes in the stored volume of Orós Reservoir, yielding a sensitivity index (SI) of only 0.21 . For example, by doubling the storage capacity of non-strategic reservoirs, the HCI decreased by $20 \%(\mathrm{HCI}=5.5 \%)$, and the stored volume in Orós Reservoir would be reduced by only $1.3 \%$, when compared with the reference volume $\left(1520 \mathrm{hm}^{3}\right)$, thus resulting in a sensitivity index (SI) of only 0.06 .

Thereby, if the storage capacity of small and medium reservoirs spread out in Orós Reservoir Basin increased by $100 \%$, the volume retained by them would not significantly affect the volume stored in Orós Reservoir. Or yet, if the 4664 reservoirs were removed, thus forming, the reservoir network denominated Rn123, the HCI would fall to 4\% (59\% less). However, the stored volume in Orós Reservoir would increase to $280 \mathrm{hm}^{3}$. This increase is considered to be very small (IS=0.09), because the direct catchment area of Orós Reservoir would increase from $996 \mathrm{~km}^{2}$ to $12340 \mathrm{~km}^{2}$ after the removal of these thousands of reservoirs (Figure 4).

Rev. Ambient. Água vol. 14 n. 4, e2367 - Taubaté 2019 

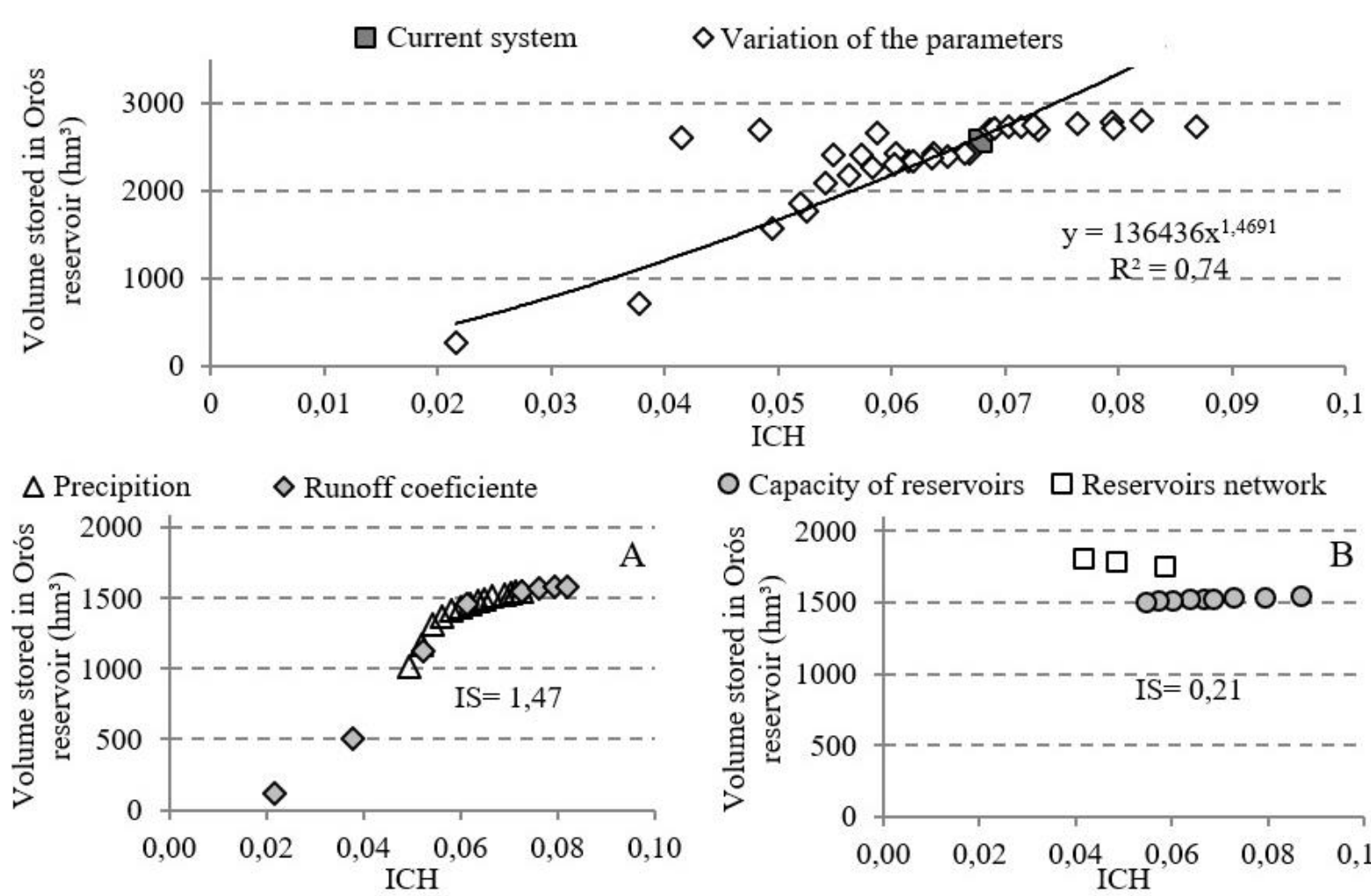

O Capacity of reservoirs $\square$ Reservoirs network

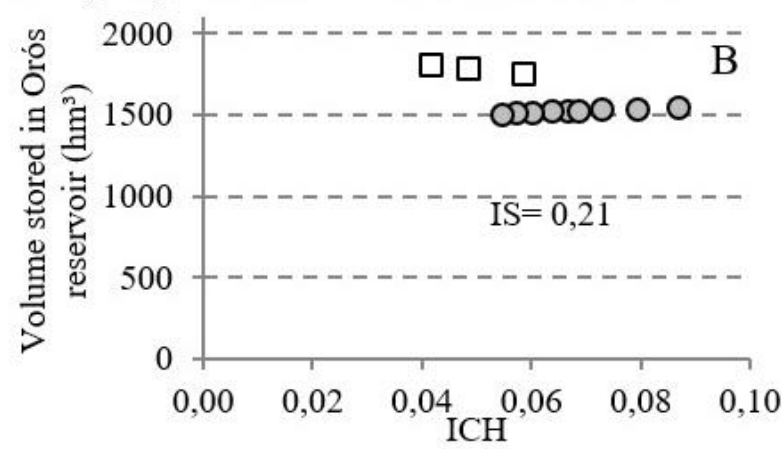

Figure 3. Highlighted: Relation between the Hydrological Connectivity Index (ICH) with the stored volume in the hydrographic basin of Orós dam (BHAO), according to the simulation of the scenarios in the ResNetM model, for the period of 1991 to 2011. In figures A and B: Relation between the hydrological connectivity index (ICH) and the volume stored in Orós dam, according to the variation of the natural (A) and anthropic (B) elements of major relevance for the hydrological connectivity of BHAO.

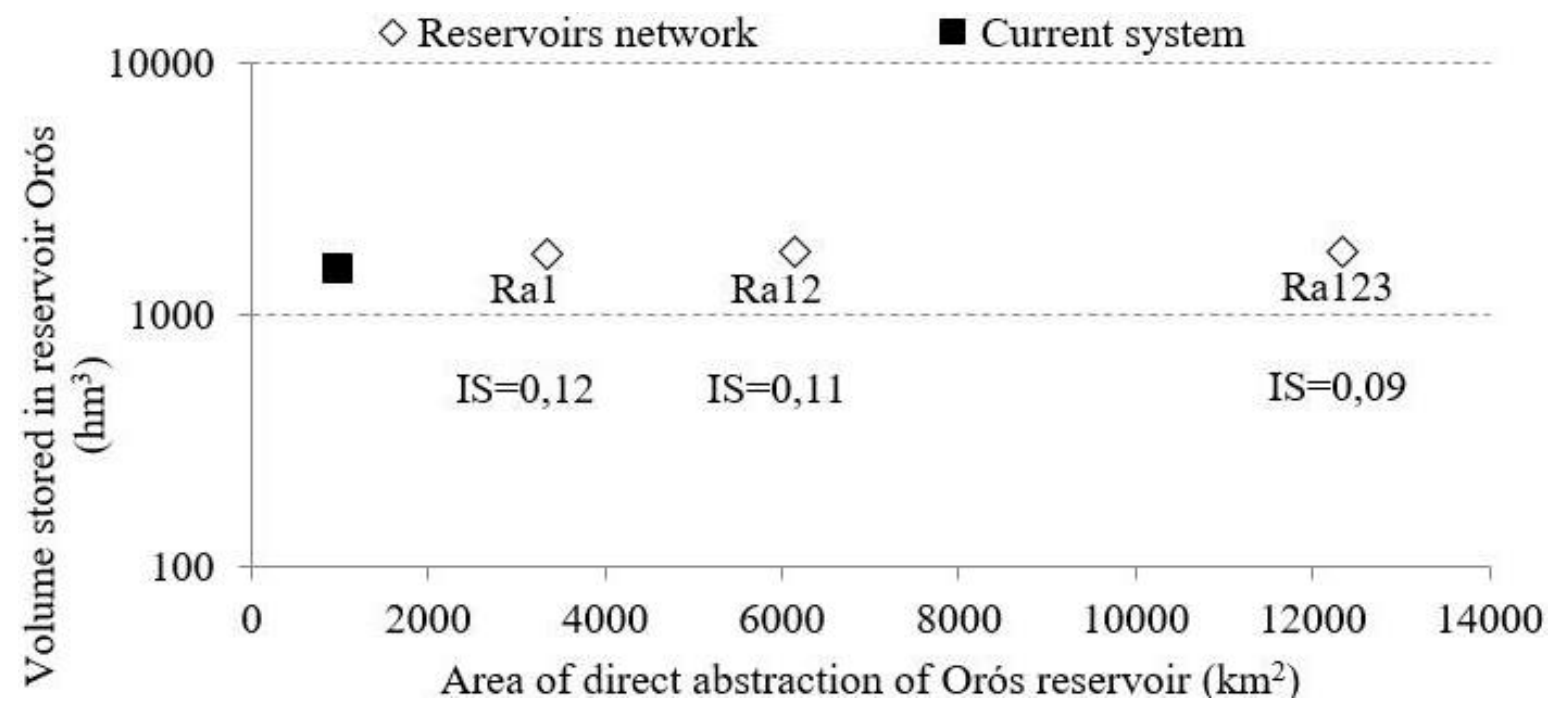

Figure 4. Relation between the direct catchment area and the average stored volume of Orós dam, obtained in the simulation of the current BHAO System and of the reservoir network variation (Ra).

The low influence of the HCI, calculated by changing the reservoir dense network topology over the stored volume in Orós Reservoir, was a surprising result. However, this is evidence that the volume of Orós Reservoir has low sensitivity to the presence or absence of the thousands of small- and medium-sized reservoirs built upstream over the years $(\mathrm{SI}=0.12)$. Thus, one can affirm that the spatial distribution of water performed by the high-density 
reservoir network (HdRN) of Orós Reservoir Basin has not been causing any significantly negative impact over the stored volume and, consequently, over the water availability of Orós Reservoir, if the superficial runoff and rainfall conditions inside the basin do not decrease.

The expansion of water-resource development has been a threat to the natural flow regime and the ecological integrity of rivers and streams in the Brazilian semi-arid region. Efforts to manage and conserve the natural flow regime of these systems is hampered by limited scientific information on processes that lead to high natural variability in the water flow regime (Maltchik and; Medeiros, 2006; Santos et al., 2017). Although there is a consensus that the main impacts of reservoirs are a decrease in river discharges, peak flows due to water abstraction from reservoirs and water loss, impacts on low river flow may vary from basin to basin due to many types of reservoirs and their different uses, a factor that makes it difficult to anticipate the estimation of hydrological connectivity even using several types of indicators (Habets et al., 2018). However, there is still a lack of data on the flows of these waterways, which increases the need to apply hydrological models to this estimation; studies being developed in this estimation are important to carry out this management (Maltchik and Medeiros, 2006; Santos et al., 2017).

\section{CONCLUSIONS}

Based on the analyses performed in the present study, it can be concluded that the runoff coefficient and the reservoir network (change in the reservoir number of the network), were the parameters evaluated with the highest sensitivity of hydrological connectivity. Thus, the alteration of the landscape by man provides significant changes in river navigation between reservoirs in the basin. In the case of the topology of the reservoir network, the presence of thousands of small- and medium reservoirs is not broken, keeping the reservoir network connected even during small river floods.

The reduction of the reservoir network also provides a reduction in the hydrological connectivity of the basin; it also provides a reduction of spatial availability of water inside the basin, besides not significantly altering the inflow to the strategic reservoir of the basin, the Orós Reservoir, considered the main discharging body of the basin in this work.

\section{REFERENCES}

ARAÚJO, J. C.; BRONSTERT, A. A method to assess hydrological drought in semi-arid environments and its application to the Jaguaribe River basin, Brazil. Water $\begin{array}{lllllll}\text { International, } & \text { v. } & 41, & \text { n. } & 2, & \text { p. } & 213-230,\end{array}$ https://dx.doi.org/10.1080/02508060.2015.1113077

ARAÚJO, J. C.; PIEDRA, J. I. G. Comparative hydrology: analysis of a semiarid and a humid tropical watershed. Hydrological Processes, v. 23, p. 1169-1178, 2009. https://doi.org/10.1002/hyp.7232

BRACKEN, L.J.; CROKE, J. The concept of hydrological connectivity and its contribution to understanding runoff-dominated geomorphic systems. Hydrological Processes, v. 1763, p. 1749-1763, 2007. https://dx.doi.org/10.1002/hyp.6313

BROZOVIC, N.; HAN, J.; SPEIR, C. Spatial Dynamic Optimization of Groundwater Use with Ecological Standards for Instream Flow. In: AMERICAN GEOPHYSICAL UNION, Fall Meeting, 2011. Abstract [...] Washington: AGU, 2011. https://dx.doi.org/10.1142/S2382624X16500132 
BURKE A.R. A comparison of soil moisture and hillslope-stream connectivity between aspen and conifer-dominated hillslopes of a first order catchment in northern Utah. 2009. 125p. Thesis - Utah State University, Logan, UT. 2009.

CALLOW, J. N.; SMETTEM, K.R.J. The effect of farm dams and constructed banks on hydrologic connectivity and runoff estimation in agricultural landscapes. Environmental $\begin{array}{lllllll}\text { Modelling and Software, } & \text { v. 24, p. } & \text { 959-968, }\end{array}$ https://dx.doi.org/10.1016/j.envsoft.2009.02.003

DÖLL, P.; KASPAR, F.; LEHNER, B. A global hydrological model for deriving water availability indicators: model tuning and validation. Journal of Hydrology, v. 270, n. 2003, p. 105-134, 2003. https://dx.doi.org/10.1016/S0022-1694(02)00283-4

FRYIRS, K. (Dis)Connectivity in catchment sediment cascades: a fresh look at the sediment delivery problem. Earth Surface Processes and Landforms, v.38, n.1, p. 30-46, 2012. https://dx.doi.org/10.1002/esp.3242

GARBIN, S.; CELEGON, E. A.; FANTON, P.; BOTTER, G. Hydrological controls on river network connectivity. Royal Society Open Science, v. 6, n. 2, p. 1-20, 2019. https://dx.doi.org/10.1098/rsos.181428

HABETS, F.; MOLÉNAT, J.; CARLUER, N.; DOUEZ, O.; LEENHARDT, D. The cumulative impacts of small reservoirs on hydrology: A review. Science of the Total Environment, v. 643, p. 850-867, 2018. https://dx.doi.org/10.1016/j.scitotenv.2018.06.188

HALL, C. J.; JORDAAN, A.; FRISK, M. G. The historic influence of dams on diadromous fish habitat with a focus on river herring and hydrologic longitudinal connectivity. Landscape Ecology, v. 26, p. 95-107, 2011. https://dx.doi.org/10.1007/s10980-010-9539-1

HANASAKI, N.; INUZUKA, T.; KANAE, S.; TAIKAN OKI, T. An estimation of global virtual water flow and sources of water withdrawal for major crops and livestock products using a global hydrological model. Journal of Hydrology, v. 384, n. 3-4, p. 232-244, 2010. https://doi.org/10.1016/j.jhydrol.2009.09.028

JACKSON, C. R.; PRINGLE, C. M. Ecological Benefits of Reduced Hydrologic Connectivity in Intensively Developed Landscapes. BioScience, v. 60 n. 1, p.37-46, 2010. https://dx.doi.org/10.1525/bio.2010.60.1.8

KROL M. S.; VRIES, M. J.; VAN OEL, P. R.; ARAÚJO, J. C. Sustainability of Small Reservoirs and Large Scale Water Availability Under Current Conditions and Climate Change. Water Resour Manage, v. 25, p. 3017-3026, 2011. https://dx.doi.org/10.1007/s11269-011-9787-0

KRUK, N. S.; VENDRAME, I. F.; CHAN, C. S.; LADEIRA, F. S. B. Sensitivity Analysis of the Distributed Hydrological Model DHSVM to Vegetation Parameters. Revista

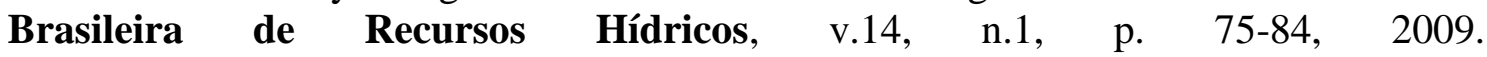
https://dx.doi.org/10.21168/rbrh.v14n1.p75-84

LANE, S. N.; REANEY, S. M.; HEATHWAITE, A. L. Representation of landscape hydrological connectivity using a topographically driven surface flow index. Water Resources Research, v. 45, n. 8, 2009. https://dx.doi.org/10.1029/2008WR007336

LONG, C. M.; PAVELSKY, T. M. Remote sensing of suspended sediment concentration and hydrologic connectivity in a complex wetland environment. Remote Sensing of Environment, n. 129, p. 197-209, 2013. https://dx.doi.org/10.1016/j.rse.2012.10.019 
LOPES, J. W. B.; PINHEIRO, E. A. R. Análise temporal da conectividade e da capacidade de transporte potencial de sedimentos em meso-bacia semiárida, CE, Brasil. Revista Agro@Mbiente on-Line, v. 7, n. 2, p. 136, 2015.

LÓPEZ-VICENTE, M.; POESEN, J.; NAVAS, A.; GASPAR, L. Predicting runoff and sediment connectivity and soil erosion by water for different land use scenarios in the $\begin{array}{lllll}\text { Spanish Pre-Pyrenees. } & \text { Catena, } & \end{array}$ https://dx.doi.org/10.1016/j.catena.2011.01.001

LOUCKS, D. P.; VAN BEEK, E. Model Sensitivity and Uncertainty Analysis. In: LOUCKS, D. P.; VAN BEEK, E. Water Resources Systems Planning and Management. Paris, 2005. p. 255-290.

MALVEIRA, V. T. C.; ARAÚJO, J. C.; GÜNTNER, A. Hydrological Impact of a High-Density Reservoir Network in the Semiarid North-Eastern Brazil. Journal of Hydrologic Engineering, v. 17, n. 1, p. 109-117, 2012. https://dx.doi.org/10.1061/(ASCE)HE.19435584.0000404

MALTCHIK, L.; MEDEIROS, E.S.F Conservation importance of semi-arid streams in northeastern Brazil: implications of hydrological disturbance and species diversity. Aquatic Conservation: Marine and Freshwater Ecosystems, v. 19, n. January, p. 127-133, 2009.

MARENGO, J. A.; TORRES, R. R.; ALVES, L. M. Drought in Northeast Brazil - past, present, and future. Theoretical and Applied Climatology, v. 129, n. 3-4, p. 1189-1200, 2017. https://dx.doi.org/10.1007/s00704-016-1840-8

MEDEIROS, P. H. A.; GÜNTNER, A.; FRANCKE, T.; MAMEDE, G.; de ARAÚJO, J. C. Modelling spatio-temporal patterns of sediment yield and connectivity at a semi-arid catchment with WASA-SED model. Hydrological Sciences Journal, v. 55, n. 4, p. 636648, 2010. https://dx.doi.org/10.1080/02626661003780409

NEARING, M. A.; DEER-ASCOUGH, L.; LAFLEN, J. M. Sensitivity analysis of the WEPP hillslope profile erosion model. TASAE, v. 3, n. 33, p. 839-849, 1990.

PETER, S. J.; ARAÚJO, J. C.; ARAÚJO, N. A. M.; HERRMANN, H. J. Flood avalanches in a semiarid basin with a dense reservoir network. Journal of Hydrology, n. 512, p 408420, 2014. https://dx.doi.org/10.1002/hyp.7232

RODRIGUES, J. O.; ANDRADE, E. M. DE; MENDONÇA, L. A. R.; et al. Respostas hidrológicas em pequenas bacias na região semiárida em função do uso do solo. Revista Brasileira de Engenharia Agrícola e Ambiental, v. 17, n. 3, p. 312-318, 2013.

SAFEEQ, M.; FARES, A. Hydrologic effect of groundwater development in a small mountainous tropical watershed. Journal of Hydrology, v. 428-429, p. 51-67, 2012. https://dx.doi.org/10.1016/j.jhydrol.2012.01.023

SANTOS, J. C. N. DOS; ANDRADE, E. M. DE; MEDEIROS, P. H. A.; PALÁCIO, H. A. DE Q.; NETO, J. R. DE A. Sediment delivery ratio in a small semi-arid watershed under conditions of low connectivity. Revista Ciencia Agronomica, v. 48, n. 1, p. 49-58, 2017.

SILVA, M. G.; AGUIAR NETTO, A. O.; NEVES, R. J. J.; VASCO, A. N.; ALMEIDA, C.; FACCIOLI, G. G. Sensitivity Analysis and Calibration of Hydrological Modeling of the Watershed Northeast Brazil. Journal of Environmental Protection, v. 6, p. 837-850, 2015. https://dx.doi.org/10.4236/jep.2015.68076 
SPEIR, C.; HAN, J.; BROZOVIC, N. Spatial Dynamic Optimization of Groundwater Use with Ecological Standards for Instream Flow. Water Economics and Policy, v. 02, n. 03, 2016. https://dx.doi.org/10.1142/S2382624X16500132

SUN, W; ISHIDAIRA, H.; BASTOLA, S.; YUA, J. Estimating daily time series of streamflow using hydrological model calibrated based on satellite observations of river water surface width: Toward real world applications. Environmental Research, v.139, p. 36-45, 2015. https://dx.doi.org/10.1016/j.envres.2015.01.002

TOLEDO, C. E.; ARAÚJO, J. C.; ALMEIDA, C. L. The use of remote-sensing techniques to monitor dense reservoir networks in the Brazilian semiarid region. International Journal of Remote Sensing, v. 35, n. 10, p. 3683 - 3699, 2014. https://dx.doi.org/10.1080/01431161.2014.915593

YANG, J. C.; WANG, Z. H.; CHEN, F.; MIAO, S. G.; TEWARI, M.; VOOGT, J. A.; MYINT, S. Enhancing Hydrologic Modelling in the Coupled Weather Research and ForecastingUrban Modelling System. Boundary-Layer Meteorology, v. 155, n. 2, p. 87-109, 2015. https://dx.doi.org/10.1007/s10546-014-9991-6 